\title{
"I have collected qualitative data; now what do I do?" approaches to analysing qualitative data
}

\author{
Dr William Evans ${ }^{1 *}$ and Dr Tom o Connor ${ }^{2}$ \\ ${ }^{1}$ Department of Nursing and Health Care Sciences, Institute of Technology Tralee, Co. Kerry, Ireland \\ ${ }^{2}$ Academic Head of Academic Affairs in the School of Nursing and Midwifery in the Royal College of Surgeons, Ireland
}

\section{Introduction}

Analysing qualitative data can be challenging for novice researchers and is best summarised by Silverman [1]: 'You have gathered your interviews, selected your documents or made some observations. Now what do you do?' [2]. There are many different ways to analyse data and decisions about which analytical approach to choose from can be challenging. The paper will introduce a number of analytical approaches from different research traditions and introduce how they can be employed when analysing qualitative data. In addition, the benefits of utilising computer assisted technology to complete qualitative data analysis will be presented.

\section{An overview of qualitative data analysis approaches}

All novice researchers need pragmatic, informed and understandable assistance in the processes of making useful data records, in handling and working with the data on the road to a good analysis and in showing that it is good. Reference (Richards, 2015 p. 6)

In order for a researcher to begin qualitative data analysis and complete 'good' analysis, a road map or heuristic pathway must be at their disposal to guide and manage all steps of this important and crucial process. This process is best guided by an analytical approach and ever before data is collected, attention should be given to deciding on the most suitable and best fit. For the purposes of this paper, an analytical approach is defined as a qualitative data analysis tool used to engage in a systematic comprehensive analysis of available data. Grbich [3] describes three elements that influence decisions around deciding on an approach to analysing qualitative research. These relate firstly, to the researcher and their views and values, secondly the design and methods that are chosen and finally, the findings and the theoretical interpretations of the analysed data. Four research areas, phenomenology, grounded theory, discourse analysis and narrative research will now be introduced, including an outline of a number of analytical approaches applicable to each one.

\section{Phenomenology}

Phenomenologists recognise that lived experience gives meaning to each person's perception of a specific phenomenon [4], therefore the research purpose is to understand human experience [5]. Silverman (2014) states that 'deep meaning can be transmitted through rich spontaneous talk' (p. 24), therefore the researchers focus is on 'looking beyond the details of everyday life to the essence underlying them' [6]. The focus from a qualitative analysis perspective therefore is to try and understand the basic structure of that experience and interpret the meaning it has for a person or group [7].
A large number of analytical approaches have emerged in phenomenology and in most cases these are linked to either Husserl's descriptive and Heidegger's interpretive research approach (Table 1). Each analytical framework has guiding principles or steps associated with analysis [8] that provide signposting on how available data is to be managed. Some important differences exist between the analytical approaches outlined below [4]. These include for example:

1. The practice of bracketing a researchers own preconceptions [9].

2. Whether or not to return to the participants for validation purposes when completing data analysis [4].

3. The emphasis on description or interpretation [10]

4. Are participants immersed or separate from the world in terms of consciousness? [3].

5. The research must become familiar with the philosophical and methodological underpinnings of phenomenology, before grounding their study in the approach that offers 'the most rigorous and accurate interpretations of the phenomenon under investigation' [9].

\section{Grounded Theory (GT)}

Grounded theory is a systematic, research approach to collecting and analysing qualitative data which aims to construct theory 'grounded' in the data [11]. The research tradition therefore is on the 'inductive generation of theory from data' [12], placing data analysis and theory building on an equal platform. Traditionally, data collection was in the form of interviews and observations [13], however greater potential exists for other methods of data collection to be utilised in GT [12] including media and audio-visual texts for example [6].

Data analysis procedures can be aligned to three leading versions of Grounded Theory namely Straussian, Glaserian and Charmaz's constructionist approach. Grbich [3] provides an excellent and insightful overview of these three analytical approaches and is a useful resource to assist in decision making. The analytical steps aligned to Charmaz's GT approach reject previous 'positivist' roots associated with both Straussian and Glaserian's work and concludes that the

Correspondence to: Dr. William Evans, EdD. MSc, PG Dip Ed, BNS, H Dip Children's Nursing, RGN, RCN, RNT, Lecturer, Department of Nursing and Health Care Sciences, Institute of Technology Tralee, Co. Kerry, Ireland, Tel: 0667191954; E-mail: william.evans@staff.ittralee.ie

Received: August 25, 2017; Accepted: September 22, 2017; Published: September 25,2017 
Table 1. Overview of analytical approaches within phenomenological research

\begin{tabular}{|c|c|c|c|c|}
\hline Author of Framework & $\begin{array}{c}\text { Descriptive, Interpretive or } \\
\text { Combined }\end{array}$ & Number of Stages & Bracketing $\mathbf{Y} / \mathbf{N}$ & $\begin{array}{c}\text { Respondent Validation/ Member } \\
\text { checking Y/N }\end{array}$ \\
\hline Paterson and Zderad [28] & Descriptive & Five & $\mathrm{Y}$ & $\mathrm{N}$ \\
\hline Colaizzi [29] & Descriptive & Seven & $\mathrm{Y}$ & Y \\
\hline Sanders [30] & Descriptive & Four & $\mathrm{Y}$ & $\mathrm{N}$ \\
\hline van Kaam [31] & Descriptive & Six & $\mathrm{Y}$ & $\mathrm{N}$ \\
\hline Giorgi [32] & Descriptive & Four & $\mathrm{Y}$ & $\mathrm{N}$ \\
\hline Hycner [33] & Descriptive & Nine & $\mathrm{Y}$ & $\mathrm{N}$ \\
\hline Diekelmann, Allen, and Tanner [34] & Interpretive & Seven & $\mathrm{N}$ & $\mathrm{N}$ \\
\hline Quinn and Clare [35] & Combined & Four & $\mathrm{N}$ & $\mathrm{N}$ \\
\hline Van Manen [36] & Combined & $\mathrm{Si}$ & $\mathrm{N}$ & $\mathrm{Y}$ \\
\hline Crist and Tanner [5] & Interpretive & Five & $\mathrm{N}$ & $\mathrm{N}$ \\
\hline Kleiman [37] & Descriptive & Eight & $\mathrm{Y}$ & $\mathrm{Y}$ \\
\hline Lindseth and Norberg [38] & Interpretive & Three & $\mathrm{Y}$ & $\mathrm{N}$ \\
\hline Grbich [3] & Descriptive & Five & $\mathrm{Y}$ & $\mathrm{N}$ \\
\hline
\end{tabular}

researcher cannot remain neutral and objective during the analytical process [14]. All proponents of GT do agree on the analytical steps that researchers adopt including: theoretical sampling, coding, constant comparison, the core variable and 'saturation' [6]. Finally, with the GT tradition, data analysis begins simultaneously with data collection [14]. Table 2 outlines a GT data analytical approach by Streubert Speziale and Carpenter [9].

\section{Discourse analysis}

Unlike phenomenology and grounded theory, discourse analysis incorporates a diversity of research approaches from several disciplines and theoretical traditions [15]. Discourse analysis is a research approach that is exclusively about the analysis of interviews, texts and recorded talk [1] concentrating on the function and use of language and its role in creating reality [16]. Language therefore is the basis from which social meaning is reproduced, social identities are shaped and facts become established [17].

Discourse analysis has a number of related theoretical strands the main ones being: Discursive Psychology, Critical Discourse Analysis (CDA) and Foucauldian Discourse Analysis. Each of these approaches have what Brown and Locke [18] describe as a 'commitment to a model of persons as sophisticated language users, able to flexibly interpret and understand their social worlds' (p. 379). Table 3 provides an overview of each one and the specific focus when completing data analysis.

Discourse analysts refrain from verifying truth claims but instead attempt to understand how discourses are constructed by employing a variety of approaches to analysis. Completing discourse analysis is described as follows by Taylor [15]:

The process of analysing discourse is not linear but exploratory and iterative. In other words, the analyst's task is not one of straightforwardly 'translating' and 'decoding' the date, one item at a time; rather, analysis involves reading, rereading an entire data set, comparing, noticing and marking points of interest and returning to them later (p. 69)

While discourse analysts decry the idea of following a step-bystep approach to discourse analysis, researchers do however employ overarching steps to aid in discourse analysis [17]. Bax [19] introduces three key questions to aid discourse analysis of texts including:

What the particular text under analysis does or achieves? How it achieves it?

Why it seeks to do so?
Table 2. An example of a grounded theory analytical approaches

\begin{tabular}{|l|l|}
\hline Step & Activity \\
\hline 1 & Data Generation \\
\hline 2 & $\begin{array}{l}\text { Concept Formation (Coding at Level 1, Substance Codes, Level 2, } \\
\text { Categorisation, Level 3, Basic Social-psychological Process identified. }\end{array}$ \\
\hline 3 & $\begin{array}{l}\text { Concept Development (Reduction Sampling, Selective Review of the } \\
\text { Literature, Selective Sampling of the Data }\end{array}$ \\
\hline 4 & Core Variable \\
\hline 5 & Theory development and research report writing [9] \\
\hline
\end{tabular}

Table 3. Overview of discourse analysis analytical approache

\begin{tabular}{|l|l|}
\hline Approach to Discourse analysis & Focus of analysis \\
\hline Discursive Psychology & $\begin{array}{l}\text { How is language constructed, situated in } \\
\text { interaction and bound up with actions [38] }\end{array}$ \\
\hline Critical Discourse Analysis (CDA) & $\begin{array}{l}\text { The role language plays in establishing } \\
\text { and perpetuating dominance and power in } \\
\text { society [15] }\end{array}$ \\
\hline Foucauldian Discourse Analysis & $\begin{array}{l}\text { A historical analysis and language; } \\
\text { examining rules, divisions, and systems } \\
\text { associated with a particular body of } \\
\text { knowledge [39]. }\end{array}$ \\
\hline
\end{tabular}

The following steps aid in what Tonkiss [17] describe as 'opening up a text' to interpretation and analysis and can be described as an analytical framework:

1. Identifying key themes and arguments

2. Looking for association and variation

3. Examining characterisation and agency

4. Paying attention to emphasis and silences

Tables 4 and 5 provide two analytical frameworks by Grbich [3]. The first offers broad heading to aid Foucauldian discourse analysis while the second is a CDA analysis approach.

\section{Narrative research}

Narrative research or inquiry involves working with narrative materials of various kinds including written, verbal, sounds or visual media that convey meaning [20]. Narratives can be found in a variety of domains including the private (e.g diaries), public (e.g newspaper article) and political (e.g speech) [21].

Squire et al. classifies narrative research as having two key areas of focus; firstly, researchers may be interested in the structural issues about language in a narrative and 'the way the story is put together' $[20,22]$. Labov and Waletzky [23] structural model of narrative analysis 
Table 4. Guidelines for foucauldian analysis

\begin{tabular}{|l|l|}
\hline Step & Activity \\
\hline 1 & $\begin{array}{l}\text { Track the historical development of the discourse over time and identify } \\
\text { the players and the social, economic and political climate which fostered its } \\
\text { development. }\end{array}$ \\
\hline 2 & $\begin{array}{l}\text { Identify constituents in terms of objects, statements, themes, arguments, traces } \\
\text { of challenges, traces of ideas that changes directions }\end{array}$ \\
\hline 3 & $\begin{array}{l}\text { Seek disunity and discontinuity and the limits of the discourse. Monitor } \\
\text { dispersion in other fields }\end{array}$ \\
\hline 4 & Locate challenges and see what happened to these [3]. \\
\hline
\end{tabular}

Table 5. CDA analytical approach

\begin{tabular}{|l|l|}
\hline $\begin{array}{l}\text { Identifying } \\
\text { Framing }\end{array}$ & Focus of analysis \\
\hline 1 & $\begin{array}{l}\text { Read the text twice: first in a general manner, next more critically } \\
\text { within the expected structure of its genre }\end{array}$ \\
\hline 2 & $\begin{array}{l}\text { Identify strategies of placement (headings, graphs, pictures, } \\
\text { keywords, etc) }\end{array}$ \\
\hline 3 & Note what could have been said (but wasn't) \\
\hline 4 & Identify whose voices are used and whose are missing? \\
\hline Interpretations & Focus of analysis \\
\hline 1 & Note use of sentences - how many on one aspect of a topic \\
\hline 2 & Who is depicted as powerful? Who is passive? Why? \\
\hline 3 & Note use of passive verbs to focus on one aspect \\
\hline 4 & Question statements the author is taking for granted. \\
\hline 5 & $\begin{array}{l}\text { Note insinuations to take power from people (minimising, comparing } \\
\text { with others) }\end{array}$ \\
\hline 6 & Note connotations such as 'terrorist' versus 'freedom fighters' \\
\hline 7 & $\begin{array}{l}\text { Note use of uncertainty (may, might, should, could) to slant } \\
\text { information [3]. }\end{array}$ \\
\hline
\end{tabular}

is a seminal framework used in narrative research (Table 6). The researchers becomes 'fascinated by the structure of these narratives, in particular the match between the reported chronological verbal sequencing of personal events compared with their order as they actually occurred, as well as how their construction conveyed meaning to the receiver' [3].

Secondly, narrative research can shed light on phenomenon about which little is known and 'tell us about lives, demonstrate cognitive and emotional realities, and interrelate with social and cultural worlds [20]. Here the focus of the research is on content and on what the substantive elements of the accounts tell us about the social world [22]. The focus therefore is on identifying content categories or themes that emerge from each narrative [20]. A useful analytical approach by Gibbs [24] describes a number of steps to narrative analysis (Table 7).

\section{The use of computer assisted technology in analysing qualitative data}

There is a growing acknowledgement and acceptance of the benefits of technology when completing qualitative data analysis. Programmes such: NVIVO, ATLAS.ti and MAXQDA can efficiently assist in the management of many forms of qualitative data including written, audio and visual material.

The benefits of employing software packages to assist in qualitative data analysis are outlined in Table 8 . One specific criticism levelled at the use of computer assisted programmes relates to the potential to become distant from the data once the process of data analysis begins [24]. This risk however is much greater in manual approaches, where the 'scissors' or 'highlighter pen' can become more potent in making context remote and distant and difficult to retrieve, particularly in large studies with masses of data. An important point to note however is that while there are benefits to employing technology to aid qualitative analyses, the thinking and interpretive activity is the sole responsibility of the researcher. Technology can support the researcher in all stages analysis and write-up [25] but is not an alternative to absolute and complete data emersion [26]. The challenging work of exploring, thinking and decision-making still has to be completed by the analyst however [15].

A more compelling argument that supports the use of technology to aid qualitative data analysis relates specifically to enhancing rigour and transparency around how interpretation and analysis evolve and manifest. For example, a critical output associated with many of the analytical frameworks outlined earlier, include the unearthing of key patterns, categories and themes. Evidently, this necessitates the researcher to manually produce a schemata that maps and illustrates how such intricate interpretative activity unfold from the very beginning to the end of the process. This step alone is more effectively retrieved and displayed when employing appropriate computer assisted software such as NVIVO for example. Ongoing reflections in the form of analytical outputs and tables can be produced and revised seamlessly at both macro and micro level. Evidence such as this can demonstrate how analysis progresses, as well as introducing outputs from iterative stages of analysis that were completed along the way. In addition, the use of additional tools including analytical memos and annotations linked to specific themes assist in establishing rigour by displaying steps in how decision-making occurred [27]. This contrasts with Richards and descriptions of how manual coded passages were previously filed and recorded: 'Then your little thoughts were written in the document margins, or filed with the ideas, or worse, distributed around your environment, on yellow stickers that fell off in the bus' [2].

\section{Conclusion}

Qualitative researchers deal with and revel in, confusing, contradictory, multifaceted data records, rich documents of experience and interaction [2]. At the early stages of a research project, completing qualitative data analysis can equate to 'exploring a new territory without an easy-to-read map' [1]. Considerations as to the most suitable analytical approach to choose from can be challenging and should be made early in a research project. Each research analytical

Table 6. Structural model of narrative analysis

\begin{tabular}{|l|l|}
\hline Focus of analysis & Description \\
\hline Abstract & Summary of the subject matter \\
\hline Orientation & $\begin{array}{l}\text { Information about the settings: time, place, situation, } \\
\text { participants }\end{array}$ \\
\hline Complicating action & What eventually happened, what happened next \\
\hline Evaluation & What the events mean to the narrator \\
\hline Resolution & How it all ended \\
\hline Coda & Return the perspective to the present $[23]$ \\
\hline
\end{tabular}

Table 7. Analytical approach narrative tradition

\begin{tabular}{|l|l|}
\hline Step & Activity \\
\hline 1. & Read and reread transcript/ Look for common content and themes \\
\hline 2. & Prepare a short written summary to identify key features \\
\hline 3. & $\begin{array}{l}\text { Use right-hand margin of the transcript to note thematic ideas and structural } \\
\text { points }\end{array}$ \\
\hline 4. & Take notes and memos \\
\hline 5. & Mark as embedded mini-stories or subplots \\
\hline 6. & $\begin{array}{l}\text { Highlight or circle emotive language }, \text { imagery, use of metaphors and passages } \\
\text { about the narrators feelings }\end{array}$ \\
\hline 7. & Code thematic ideas and develop a coding frame \\
\hline 8. & Connect literature and ideas and themes \\
\hline 9. & Undertake case by case comparison \\
\hline
\end{tabular}


Table 8. Benefits to employing software packages to assist in qualitative data analysis

1 Provides a single repository of all data which is easily accessible.

2 Allows viewing of retrieved segments of text in their original context in an easy and 2 efficient manner [40].

3 It offers an efficient means through which to manage and organize data while

3 simultaneously supporting rigorous data analysis [41].

4 Interpretations emerging from the data are robust because of the tools to query and audit the coding processes [42]

5 Facilitates researchers to complete and accurately display a comprehensive audit trail 5 of all decisions in relation to interpretation [43]

Technology handles categories much more flexibly and efficiently than 'filing 6 cabinets' [2] and manual folders.

7 It expands creativity, extends research skills and facilitates analytical engagement with all the data [44].

8 The researcher can analyse aural and visually data simultaneously [42]/

9 There is a need for less typing because text can be copied into the final research 9 report or manuscript [26].

10 The risk of becoming distant from data is much greater in manual approaches, where 10 the 'scissors' can become more potent in making context remote [54].

approach asks different questions of qualitative data and it is incumbent that it is both congruent with the research questions and research approach. The overview of analytical approaches presented here offers readers some early observations into alternative ways of analysing qualitative data; further more in depth reading is necessary to ascertain a best fit for individual research studies. Finally, the use of computer assisted technology is a significant aid in managing and assisting with completing qualitative data analysis and provides an accessible platform to display quality and overall transparency within a research project.

\section{Reference}

1. Silverman D (2014) Interpreting qualitative data. London: Sage Publications.

2. Richards, Lyn (2015) Handling qualitative data: A practical guide / lyn richards. London: SAGE.

3. Grbich C (2013) Qualitative data analysis: An introduction (2nd ed.) London: Sage Publications.

4. Polit DF, Beck TB (2012) Nursing research: Generating and assessing evidence for nursing practice. London: Lippincott, Williams and Wilkins.

5. Crist JD, Tanner CA (2003) Interpretation/analysis methods in hermeneutic interpretive phenomenology. Nurs Res 52: 202-205. [Crossref]

6. Cohen L, Manion L, Morrison K (2011) Research methods in education. London: Routledge Taylor Francis Group.

7. Newton Suter W (2012) Introduction to educational research: A critical thinking approach. Los Angeles, CA [etc.]: SAGE.

8. McCance T, Mcilfatrick S (2008) Phenomenology. In W Rogers, H McKenna, S Cowman, J Keady (Eds.), Nursing research: Designs and methods, Edinburgh: Elzevier, Churchill Livingstone, pp: 231-242.

9. Streubert Speziale H, Carpenter Rinaldi D (2007) Qualitative research in nursing: Advancing the humanistic imperative. Philadelphia: Lippincott Williams \& Wilkins.

10. Giorgi A, Giorgi B (2008) Phenomenological psychology. In c. Willig w. S. Rogers (eds), handbook of qualitative methods in psychology. In C. Willig \& W. Stainton Rogers (Eds.), The sage handbook of qualitative research in psychology, Los Angeles, Calif.; London: SAGE Publications, pp: 165-178.

11. Charmaz K (2006) Constructing grounded theory: A practical guide through qualitative analysis. London: Sage.

12. Seale C (2012) Generating grounded theory. In C. Seale (Ed.), Researching society and culture (3 edn), London: Sage Publications, pp: 393-404

13. Boswell C, Cannon S (2011) Introduction to nursing research: Incorporating evidence based practice. Burlington: Jones and Bartlett Learning.

14. Charmaz K, Henwood K (2008) Grounded theory. In C. Willig \& W. S. Rogers (Eds.), Handbook of qualitative methods in psychology, London: Sage, pp: 240-259.

15. Taylor S (2013) What is discourse analysis? London: Bloomsbury.
16. Beedholm K, Lomborg K, Frederiksen K (2014) Discourse analysis and the impact of the philosophy of enlightenment in nursing research. Nurs Inq 21: 112-120. [crossref]

17. Tonkiss F (2012) Discourse analysis. In C. Seale (Ed.), Researching society and culture, London: Sage Publications, pp: 405-423.

18. Brown SD, Locke A (2008) Social psychology. In C. Willig \& W. S. Rogers (Eds.) Handbook of qualitative methods in psychology, London: Sage, pp: 373-389.

19. Bax S (2011) Discourse and genre: Analysing language in context. Palgrave Macmillan Basingstoke.

20. Squire C, Davis M, Esin C, Andrews M, Harrison B, et al (2014) What is narrative research? London: Bloomsbury.

21. Griffin A, May V (2012) Narrative analysis and interpretitive phenomenological analysis. In C. Seale (Ed.), Researching society and culture (3 edn), London: Sage Publications, pp: 441-458.

22. Elliott J (2005) Using narrative in social research: Qualitative and quantitative approaches. London: Sage.

23. Labov W, Waletzky J (1967) Narraitve analysis. In J. Helm (Ed.), Essays on the verbal and visual arts. Seattle: University of Washington Press.

24. Gibbs G (2007) Analysing qualitative data. London: Sage.

25. Spencer Ll, Ritchie J, O’Connor W, Morrell G, Ormston R (2014) Analysis in practice. In J. Ritchie, J. Lewis, C. McNaughton Nicholls \& R. Ormston (Eds.), Qualitative research practice: A guide for social science students and researchers. London: Sage Publications.

26. Cope DG (2014) Computer-assisted qualitative data analysis software. Oncol Nurs Forum 41: 322-323. [crossref]

27. Silver C, Lewins A (2014) Using software in qualitative research: A step-by-step guide. London: Sage Publications

28. Paterson JG, Zderad LT (1976) Humanistic nursing. New York: John Wiley \& Sons

29. Colaizzi Paul F (1978) Psychological research as the phenomenologist views it. In: R S. Valle \& M. King (Eds.), Existential phenomenologic al alternatives for psychology, New York: Oxford University Press, pp: 48-71.

30. Sanders P (1982) Phenomenology: A new way of viewing organizational research. Academy of Management Review 7: 353-360.

31. van Kaam A (1984) Existential foundation of psychology. New York: Doubleday.

32. Giorgi A (1985) Phenomenology and psychological research. Pittsburgh: Duquesne University Press.

33. Hycner Richard H (1985) Some guidelines for the phenomenological analysis of interview data. Human Studies 8: 279-303.

34. Diekelmann L, Allen D, Tanner C (1989) The nln criteria for appraisal of baccalaureate programs: A critical hermeneutic analysis. New York: NLN Press.

35. Quinn C, Clare L (2008) Interpretative phenomenological analysis. In H. McKenna S. Cowman, J. Keady \& R. Watson (Eds.), Nursing research: Designs and methods, Edinburgh: Elsevier; Churchill Livingstone, pp: 375-384.

36. Van Manen, Max (1990) Researching lived experience: Human science for an action sensitive pedagogy. [Albany, N.Y.]: State University of New York Press.

37. Kleiman S (2004) Phenomenology: To wonder and search for meanings. Nurse Res 11: 7-19. [crossref]

38. Lindseth A, Norberg A (2004) A phenomenological hermeneutical method for researching lived experience. Scand J Caring Sci 18: 145-153. [crossref]

39. Wiggins S, Potter J (2008) Discursive psychology. In C. Willig \& W. Rogers (Eds.), The sage handbook of qualitative methods in psychology, London: Sage Publications, pp: 73-90.

40. Arribas-Ayllon M, Walkerdine V (2008) Foacauldian discourse analysis. In C. Willig \& W. S. Rogers (Eds.), The sage handbook of qualitative methods in psychology, London: Sage, pp: 91-108.

41. Bazeley P (2007) Qualitative data analysis with nvivo. London: Sage Publications Ltd

42. Banner DJ, Albarrran JW (2009) Computer-assisted qualitative data analysis software: A review. Can J Cardiovasc Nurs 19: 24-31. [crossref]

43. Bergin M (2011) Nvivo 8 and consistency in data analysis: Reflecting on the use of a qualitative data analysis program. Nurse Researcher 18: 6-12. [crossref] 
44. Ward DJ, Furber C, Tierney S, Swallow V (2013) Using framework analysis in nursing research: A worked example. J Adv Nurs 69: 2423-2431. [crossref]

45. Punch KF (2009) Introduction to research methods in education. London: Sage Publications.

46. Creswell John W (2013) Qualitative inquiry and research design: Choosing among five approaches. Los Angeles: SAGE Publications.

47. Denzin Norman K, Lincoln Yvonna S (2005) The sage handbook of qualitative research. Thousand Oaks: Sage Publications.

48. Guba Egon G, Lincoln Yvonna S (1989) Fourth generation inquiry. Newbury Park, CA: Sage.

49. Guba Egon G, Lincoln Yvonna S (2005) Paradigmatic controversies, contradictions, and emerging confluences. In N. K. Denzin \& Y. S. Lincoln (Eds.), The sage handbook of qualitative research, Thousand Oaks: Sage Publications, pp: 191-216.
50. Lather P (2004) Critical inquiry in qualitative research: Feminist and post-structural perspectives: Science "after truth." In K. De Marrais \& L. S (Eds.), Foundations for research: Methods of inquiry in education and the social sciences. Manwah: Taylor $\&$ Francis.

51. Morse JM (2015) Critical analysis of strategies for determining rigor in qualitative inquiry. Qual Health Res 25: 1212-1222. [crossref]

52. Patton Michael Q (2002) Qualitative research and evaluation methods. Thousand Oaks, Calif.: Sage Publications.

53. Stronach I (2008) On promoting rigor in educational resarch: The example of the uk's reseach assessment exercise. In N. K. Denzin \& M. D. Giardina (Eds.), Qualitative inquiry and the politics of evidence, Walnut Creek: Left Coast Press, pp: 80-97.

54. Evans W (2013) I am not a dyslexic person. I'm a person with dyslexia. An examination of dyslexic identities and related discourses within nurse education in Ireland. Sheffield: Universtiy of Shefield.

Copyright: @2017 Evans W. This is an open-access article distributed under the terms of the Creative Commons Attribution License, which permits unrestricted use, distribution, and reproduction in any medium, provided the original author and source are credited. 